\title{
EVALUATION OF TWO RAPID DIAGNOSTIC METHODS FOR ROTAVIRUS IN BOVINE FAECES
}

\author{
Hala, A. Salem ${ }^{*}$ and Hanaa, A. A. Ghoniem ${ }^{* *}$ \\ * Dept. Of virology, Animal Health Research Institiute, Dokki, Giza \\ ** Animal Reproduction Resarch Insitute, Al- Haram, Giza
}

\begin{abstract}
Rotaviral infections are common cause of economically important calf diarrhea through out the world, Specific, rapid and accurate diagnosis are required to control the disease and animal loss, dipstick (imunnochromatographical test) and enzyme linked immunosorbent assay (ELISA) were used for detection of rotavirus in fecal samples from fifty diarrheic calves were collected from private farms of Alexandria Governorate Bovine Rota virus was detected in $30 \%$ of sample which collected from the affected animals using dipstick and ELISA-Dipstick is economical, specific, rapid, easy to use, easy to read and doesn't require equipments or skilled personnel and can be used as alternative for ELISA in under developed countries, small number of daily samples and in laboratories lack. ELISA can detect small amounts of bovine rotaviral particles in faeces, can be completed in less than 4 hours and can be used as routine diagnostic for screening of large numbers of specimens.
\end{abstract}




\section{INTRODUCTION}

Bovine rotavirus $(\mathrm{RV})$ is one of the viruses which replicates in the calf intestine (Woode et al., 1974) and this agent alone, or in combination with other enteropathogens, can contribute to field outbreaks of disease (Woode, 1982). Rotavirus destroys small intestinal enterocytes resulting in diarrhea which is accompanied by a profuse fecal shedding of virus (Mebus et al., 1971).

Rotaviruses are an important cause of acute gastroenteritis in infants and young children in developed countries (Davidson etal., 1975 and Kapikian et al ., 1976) In less developed countries, rotavirus infections often result in diarrhea, dehydration and death (Walsh and waaren ., 1979 and Black et al., 1980).

Rotavirus is non enveloped viruses belonging to the genus Rotavirus in the family Reoviridae. Group A rotaviruses are the major causes of enteric disease in calve (Kapikian et al., 1986 and lucchelli et al., 1992).

Laboratory diagnosis of rotavirus infection in calves has been based on identification of viral particles, antigens or nucleic acids in fecal samples (Maes et al., 2003).

Specific, rapid and accurate methods are required for diagnosis of rotavirus (RV) as a cause of Diarrhea to control the disease and prevent animal loss (Benfield etal., 1984). Theses include ELISA (Czeruy and Eichhorn, 1989 and Athanassious etal., 1994), electron microscopy (EM), virus isolation (VI), passive hemagglutination, immunoelectroph- 
oresis, latex agglutination (LA) tests (Haikala etal., 1983 and Kaminjolo and Adesiyum, 1994) and reverse transcriptase- polymerase chain reaction (RT-PCR) (Maes etal., 2003).

In this study we use bovine Rotavirus check kit which is an imunochrmatographical method and ELISA (commercial kit) for rapid detection of bovine rotavirus in fecal samples.

\section{MATERIAL AND METHODS}

\section{1- Samples:}

Fifty fecal samples of diarrheic calves less than one month from private farms of Alexandria Governorate. Samples obtained during the period from September to December 2011, coded and stored at $20^{\circ} \mathrm{C}$.

\section{2- Techniques for fecal examination:}

\section{Bovine Rota Dipstick:}

The test was performed with a homogenous immunochromatorgraphic system with gold particules (Cypress diagnostics. Belgium). It is a ready to use test which only needs a fecal samples dilution with the supplied ready to use dilution buffer. The immunochromatographic sticks is coated with a polyclonal immunoreagent specific for rotavirus. Liquid sample together and gold conjugate both migrate by capillarity and reach the first specific anti-Rotavirus polyclonal reagent. If Rotavirus is present in the sample, it is blocked and immunoreaction appears as a red- blue line. As sample still migrates, it reaches the second non-specific antimouse IgG which gives rise to a second red-blue line. This rear line 
indicates that the chromatography has been developed without hindrance. It appears also with negative samples.

\section{ELISA Kit (Cypress diagnostic, Belgium):}

The test uses 96- well microtitration plates sensitized by specific antibodies for the bovine Rotavirus type A. These antibodies allow a specific capture of the corresponding pathogens, which are present in the fecal samples. Rows A,C, E,G have been sensitized with these antibodies and rows $\mathrm{B}, \mathrm{D}, \mathrm{F}, \mathrm{H}$ are containing non -specific antibodies. These control rows allow the differentiation between specific immunological reaction and non specific bindings to eliminate false positives. Fecal samples are diluted in dilution buffer and dispensed in the wells and incubated in the micro plates for 60 minutes at room temperature $\left(18-25 \mathrm{C}^{\circ}\right)$.

After that, the plate is washed and incubated for 60 minutes with the conjugate-peroxidase labelled anti-Rotavirus type A specific monoclonal antibody. The plate is washed again and the chromogen (Tetra-Trimethyl Benzidine TMB) is added. If Rotavirus type $\mathrm{A}$ is present in the tested faeces, The conjugate remains bound to the corresponding micro wells and the enzyme catalyses the transformation of the colorless chromogen into a pigmented compound. The intensity of the resulting blue colour is proportionate to the titer of Rotavirus in the sample. Enzymatic reaction can be stopped by acidification and resulting optical density at $450 \mathrm{~nm}$ can be recorded using a photometer. The signals recorded for the negative control microwells are subtracted from the corresponding positive microwells. 


\section{RESULTS}

Fifteen fecal samples (30\%) were detected positive and 35 fecal samples $(70 \%)$ were detected negative with both techniques used in the current study.

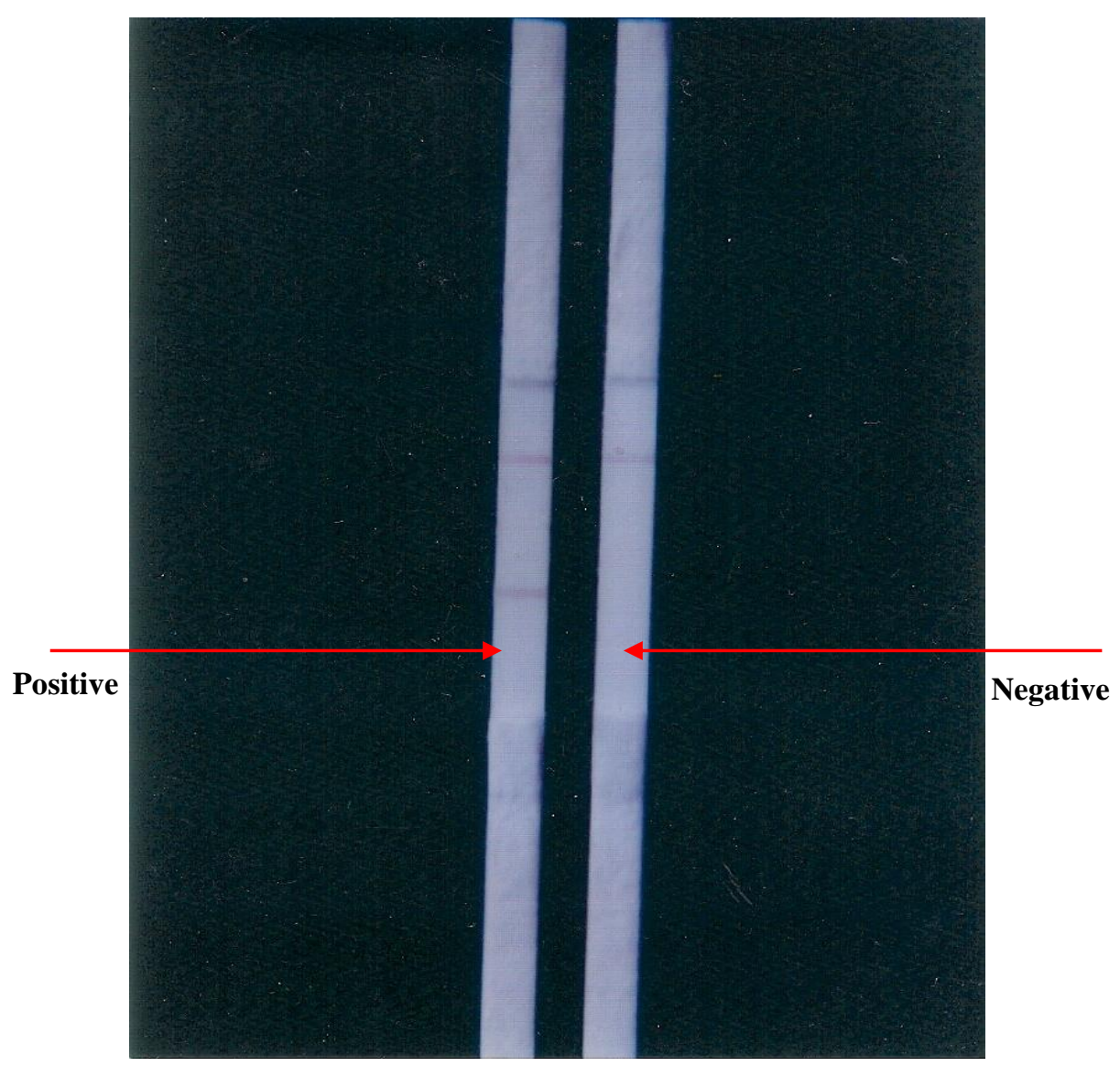

Fig. (1): Showing positive strip with two red-blue lines and negative strip with one red-blue line for Rotavirus Dipstick.

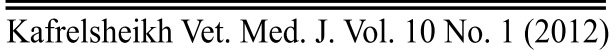


Table (1): Results of Dipstick and ELISA Kit for BRV in the tested fecal samples

\begin{tabular}{|c|c|c|c|c|c|}
\hline \multirow[t]{2}{*}{ Test } & \multirow{2}{*}{ Total Number } & \multicolumn{2}{|c|}{ Positive samples } & \multicolumn{2}{|c|}{ Negative samples } \\
\hline & & Number & Percentage & Number & Percentage \\
\hline Dipstick & 50 & 15 & 30 & 35 & 70 \\
\hline ELISA & 50 & 15 & 30 & 35 & 70 \\
\hline
\end{tabular}

\section{DISCUSSION}

Rotaviral infection are proven to be a common, economically important cause of calf diarrhea through out the world (Theil.1990) So rapid, Simple and accurate diagnosis of BRV is required.

Virus isolation (VI), fluorescent antibody technique (FA) and electron microscopy (EM) are used by diagnostic laboratories for detection of BRV in faeces (Benfield etal., 1984 and Al-Yousif etal., 2001). VI talkes 3 to 8 days before the BRV cytopathic effect develops in the cells (AL-Yousif etal,, 2001). FAT May fail to detect infected enterocytes in calves in the later stages of infection (De Beer etal., 1997) . EM achieves definitive results only when greater than $10^{6}$ to $10^{8}$ virus particles per $\mathrm{ml}$ of faeces (Benfield etal., 1984) LA test is rapid and sensitive but slides must be read without delay (Al-Yousif etal., 2002).

ELISA is good for laboratories handling large numbers of samples per day (Howe etal., 2008), sensitive and can be completed in less than 4 hours (De Beer etal, 1997). 
Immunochromatographical test (dipstick) has many advantages over other tests due to its rapidity, sensitivity, specificity, simplicity and the need for minimal training personnel and the formation of permenant lines allows the results to be read at any time convenient for the technician (Iman etal., 2009).

In the current study, we used dipstick for diagnosis of bovine rotavirus type A and commercial ELISA Kit to compare between results of the two methods.

Our data showed agreement between the results of both methods used in this study and also they agreed with results obtained by $\boldsymbol{A l}$ Yousif et al., (2002).

On conclusion, we recommended the use of dipstick for detection of BRV type A because of its advantages which are reading with naked eye, economic, specific and easy to use, no equipments needed so it can be used for diagnosis in the filed, office or laboratory as good alternative to ELISA for routine diagnostic screening of small numbers of specimens. Also it can be used in underdeveloped countries which lack facilities for ELISA and less trained personnel. ELISA can be used for routine diagnostic screening of large numbers of daily specimens and when facilities are found in the laboratory.

\section{REFERENCES}

- Al- Yousif, Y.; Anderson, J.; Chard-Bergstrom C.: Bustamante, A.; Muenzenberger,M.; Austin,K. and Kapil, S.(2001): Evaluation of latex agglutination kit (Virogen Rotatest) for detevtion of bovine rotavirus in fecal samples Clin. Diagn. Lab. Immunal. 8 : 496-498. 
- Al-Yousif, Y.; Anderson, J.; Chard-Bergstrom, C and Sanjay, K. (2002): Development, evaluation and application of lateral- flow immunoassay (Immunochromatography) for detection of Roatvirus in Bovine fecal samples. CLin. Diag. lab. Immunol., Vol9 (3):723-725.

- Athanassious,R.; G. Marsolias; R.Assaf; S-Dea; J.Descoteaus; R.Dulude and C.Montpetit (1994): Detection of bovine coranavirus and type ARotavirus in neonatal calf diarrhea and winter dysentery of cattle in Quebec: Evalution of three diagnostic methods. Can.Vet. J.35:163-169.

- Benfield.D.A.; Stotz, I.J.; Nelson, E.A. and Groon,K.s. (1984): Comparison of commercial enzyme linked immunosorbent assay with electron microscopy, fluorescent antibody and virus isolation for the detection of bovine and porcine rotavirus. Am.J.Vet. Res.45: 1998-2002.

- Black, R.E; M.H.Merson; A.S.M.M. Rahman; M. Yunis; A. R. M. A. Alim; I.Huq; R.H.Yolken and G.T. curlin (1980): A two-year study of bacterial, viral and parasitic agents associated with diarrhea in rural Bagladesh.J.Infect. Dis.142:660-664.

- Czery, C.P. and W. Eichhorn (1989): Characterization of monoclonal and polyclonal antibodies to bovine enteric coronvirus : establishment of an efficient ELISA for antigen detection in faeces. Vet.Microbial 20:111-122.

- Davidson, G.P.,R.F Bishop; R.R.W.Townley;I.H.Holmes and B. J. Ruck.(1975): Importance of a new virus in acute sporadic enteritis in children - lancet.1:242-246. 
- DeBeer, M.; Peenze, I.; De costa, V.M. and Stecle, A.A.(1997): Comparison of electron microscopy, enzyme linked immunosorbent assay and latex agglutination for the detection of bovine Rotavirus in faeces.J.S.A for Vet.Assoc.68:93-96.

- Haikala, O.J.;J.O. Kokkonen and M.K. Leinone(1983): Rapid detection of Rotavirus in stool by latex agglutination: Comparison with radioimmunoassay and electron microscopy and clinical evaluation of the test.J.Med. Virol.11:91-97.

- Howe,L.:Sugiarto,H. and Squires,R.(2008): Use of polymerase chain reaction for the differentiation of Group A bovine rotavirus G6 , G8 and G10 genotypes in the North Island of New Zealand. New Zealand veterinary Journal, 56 (5): 218-221.

- Iman,M.Bastawecy; El-Fayuomy.M.M. ans Abd El-Samee,A.A. (2009): Immunochromatographical test for rapid diagnosis of rotavirus and coronavirus in neonatal calf diarrhea.J.Egypt Vet. Med. Assoc.69(1):87-97.

- Kaminjolo, J.S. and Adesiyum, A.A.(1994): Rotavirus infection in calves, piglets, lambs and goat kids in Trinidad. Br. Vet. J. 150:293299.

- Kapikian, A.Z.; H.W.Kim; R.G. Wyatt and W.l. Cline (1976): Human reovirus- like agent as the major pathogen associated with "winter" gastroenteritis in hospitalized infants and young children. N. Engl. J. Med. 297:965-972.

- Kapikian, A.Z.; J.Flores; Y.Hoshino; R.J.Glass: K.Midthun; M.Gorziglia and R.M. Chanock (1986): Rotavirus; the major etiologic agent in severe infantile diarrhea may be controllable by a Jennerian approach to vaccination.J.Infect. Dis. 153:815-822. 
- Klein,D.; Kern,A; Lapan,G.; Benetka,V.;Mostl,K.:Hassl,A and Baumgatner,W.(2008): Evalution of rapid assays for the detection of bovine coronavirus, Rotavirus $\mathrm{A}$ and Cryptosporidium parvum in faecal samples of calves.Veterinary Journal, in press.

- Lucchelli, A.; S. Lance; P.B.Bartlett; G.Y. Miller and L.J.Saif (1992): Prevalence of bovine group A rotavirus shedding among dairy calves in Dhio. Am.j.Vet. Res 53:169-174.

- Maes,R.K.; Grooms, D.l.; Wise, A.G.; Han, C.; Ciesicki , V., Hanson, L., Vickers, M.l.; Kanitz, C. and Holland, R.(2003): Evaluation of a human group A Rotavirus Assay from one-Site Detection of bovine rotavirus.J.Clin, Microbiol. 41(1):290-294.

- Mebus, C.A,; Stair, E.I; Underdahl,N.R.; Twiehaus, M.J(1971): Pathology of neonatal calf diarrhea induced by a reolike virus. Vet. Pathol. 8:490-505.

- Theil, K.W. (1990): Group A rotaviruses. In : Viral diarrheas of man and animals, ed, Saif L J , Theil KW PP-35-77 CRC Press, Inc. Boca Ration, Fl.

- Walsh, J.A. and K.S. Warren (1979): Slective primary health care : an interim strategy for disease control in developing countries. N.Engl. J.Med.301: 967-974.

- Woode, G.N.(1982): Virus infections of the gastrointestinal tract. Ed. D.A. J.Tyrrell and A.Z. Kapikian. New York, Marketl Dekker. P 295.

- Woode, G.N.; Bridger., J.C; Hall, G.A and Dennis, M.J (1974): The isolation of a reovirus - like agent associated with diarrhea in colostrums-deprived calves in Great Britain. Res.Vet. Sci.16:102. 


$$
\begin{aligned}
& \text { تقييم اختبارين سريعين لتنخيص فيروس الرونا في اسهالات العجول }
\end{aligned}
$$

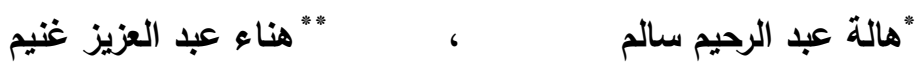

$$
\begin{aligned}
& \text { " قسم الفيروسات معهد بحوث صحة الحيوان - الدقي } \\
& \text { " معهد بحوث النتاسليات بالهرم }
\end{aligned}
$$

تعتبر العدوى بفيروس الروتا من الأسباب الهامة من حيث التأثير على الاقتصاد والانتشار في

العالم لللك يتطلب التشخيص لهذه العدوى اختبارات أكيدة وسريعة ومتخصصة لسرعة الوصول إلى حلول والتحكم في المرض والسيطرة عليه والحد من حدوث وفيات وقد تم استخدام اختبار الكروماتجرافي المناعي (dipstick) واختبار الاليزا في هذه الدراسة للكثف عن فيروس الروتا في 50 عينة براز من العجول حديثة الولادة التي بها اسهال وكانت النتيجة 30\% إيجابي لفيروس الرونا في كلا من التجربتين (اختبار الكروماتجرافي المناعي واختبار الاليزا). لذا يعتبر اختبار dipstick من الاختبارات الاقتصادية والمتخصصة والسريعة سهلة الاستخدام والفحص حيث تحتاج لأقل التدريبات ولا تحتاج لأجزة ويمكن استخدامه بالتبادل مع اختبار الاليزا في الدول النامية وفي المعامل التي تستقبل عدد محدد من العينات وتفتقر لوجود إمكانيات اختبار الاليزا وعلى الجانب الأخر، يمناز اختبار الاليزا حين توفر الإمكانيات إلى الكثف عن كميات قليلة من الفيروس في الإسهالات وهو ايضا اختبار سريع يتم في أقل من 4 ساعات ويمكن استخدامه كأختبار روتيني للكثف عن الفيروس في الأعداد الكبيرة من العينات. 